\title{
The Effect of Gamified Flipped Classroom on the Improvement of Vocabulary Learning of Iranian Pre-Intermediate EFL learners
}

\author{
Farhad Fahandezh ${ }^{1}$, Asieyeh Mohammadi ${ }^{*}$ \\ ${ }^{12}$ English Department, Bandar Abbas Branch, Islamic Azad University, Hormozgan - Iran
}

\begin{abstract}
Article Information
Received 13 July 2021

Accepted 14 September 2021

Published December 20, 2021

Abstract

The current study aimed to improve vocabulary learning by using gamification in the flipped classroom context. To this end, all of the study's population comprised high school learners at two high schools in Roodan, a city in Hormozgan, Iran. The participants were divided into three classes, class A consisting of 40 students, class B comprising 40 students, and class $C$ consisting of thirty learners. All learners were female. In order to ensure that the learners were homogeneous, the Preliminary English Test (PET) was applied. Class A was chosen as the experimental group (gamified flipped classroom), whereas classes B and C were chosen as the control groups. Data were collected through the vocabulary and placement tests. Results indicate that gamification in the flipped context could have a significant effect on vocabulary improvement. This study suggests certain implications for English teachers, policymakers, and material developers. As a new teaching model, it offers a new method of vocabulary teaching.
\end{abstract}

Keywords: gamification; flipped classroom; vocabulary learning; EFL; pre-intermediate

\section{Introduction}

Without grammar, language's expression is constrained. An expression is impossible in the absence of vocabulary (Wilkins, 1972). The four core language skills of listening, speaking, reading, and writing are all tied to vocabulary. For the development of listening skills, information acquisition, speaking, writing, reading, and learning, a diverse vocabulary is required (Goulden, Nation, \& Read, 1990). Hence, vocabulary is the most important element of language development.

*Corresponding Author: Asieyeh Mohammadi (minamohammadi797@yahoo.com) Bandar Abbass, Hormozgan, Iran
Additionally, English vocabulary acquisition must encompass both the grasp of word meanings and the progression of vocabulary acquisition; teachers' advice can aid pupils in vocabulary acquisition (Laufer, 2001). Learning English can be difficult for second-language Learners or foreign language learners (Turgut \& Irgin, 2009). Additionally, remembering English vocabulary is a tedious and passive learning task that saps pupils' motivation to learn (C. M. Chen \& Chung, 2008).

In traditional learning and teaching approaches, students, who attend lectures, are faced with much information given by the teacher and then try to comprehend information by doing homework outside of the 
classroom. This approach has several limitations (Sams \& Bergmann, 2013). Some of the limitations are limited interaction between teacher and students, the inflexibility of lectures, and the use of strict ways of transferring knowledge (Goodwin, 2013; Toto \& Hien Nguyen, 2009).

The development of new technologies has led to the hope that it can effectively solve the learning problems of foreign language learners. Students go to an independent learning environment without time or location constraints by altering the teaching-learning process. The situation also changes the learning ways of the new generation of learners (Girmen \& Kaya, 2019). The new generation is better at using the internet. Students born after the internet have a more independent learning style and a deeper conviction in the power of technology to improve learning. Boring teaching can be changed into an active learning process by using game-based learning approaches and strategies. Learning through games can improve teamwork, communication, and social interaction among students. These instructional methods enable students to learn actively and independently (Burguillo, 2010; Jong, Lai, Hsia, Lin, \& Lu, 2013; Wu, Hsiao, Wu, Lin, \& Huang, 2012).

Overall, digital game-based learning is a useful method of learning (Wu et al., 2012). In addition, digital game-based learning can improve learning motivation (Huizenga, Admiraal, Akkerman, \& Dam, 2009) and performance (H. R. Chen \& Lin, 2016). Digital game-based language learning is advantageous since it makes use of game aspects to provide a less stressful learning environment for students
(Reinders \& Wattana, 2015). (Reinders \& Wattana, 2015)

\section{Gamification in learning}

P. Z. Chen et al. (2020) looked at how gamified classroom management affected primary students' divergent thinking and creative tendencies. The students played various roles and completed different tasks. The experiment involved two groups of primary students. The classroom management of 44 primary students was gamified, whereas the classroom management of the remaining 42 primary students was traditional. The experimental and control groups were compared to see how divergent thinking and creative tendencies differed. According to the findings of the study, role-playing in gamified classroom management increased students' linguistic divergent thinking and creative propensity in classroom tasks. Also, the results showed that gamified classroom management was operative in improving learners' creativity and served as creativity teaching for primary learners.

Alavi \& Gilakjani (2019) investigated the impact of games on the vocabulary learning of Iranian high school pupils. The vocabulary Bingo game was utilized by the researchers to achieve this goal. The participants were 40 students who were selected for the study. They were divided into 20 learners for control and 20 learners for experimental groups. The experimental group was taught utilizing a vocabulary Bingo game, whereas the control group received traditional instruction. In ten sessions, the experimental group was taught vocabulary through the use of a vocabulary Bingo game. The data was collected and analyzed using the Statistical Package for the Social Sciences (SPSS). An 
independent sample t-test was used to determine the effect of the vocabulary Bingo game on the experimental group. There were statistically significant differences in the pre-test and post-test mean scores, according to the findings. Moreover, the experimental group outperformed the control group, and the statistical results were considered in the posttest. The results also showed that the use of games is effective in enhancing students' vocabulary knowledge.

Davis et al. (2018) explored the effect of gamification in game-based learning by students' gamification experiences. The participants were 139 students in an undergraduate informatics course. The findings revealed that students' perceptions of their learning, achievement, and engagement are all improving. Furthermore, students who played recreational games had some effect on the level of engagement in the course. There were no differences in attitudes toward gamification between male and female pupils.

In Ahvaz, Bavi (2018) investigated the impact of employing entertaining activities on vocabulary learning at the elementary level. Forty female students were chosen from among the eighty students that took part in the study to accomplish so. They were enrolled in an English institute to study the language. Their ages ranged from eight to fifteen. As a pre-test, the teacher constructed an exam based on Hill's book. They were split into two groups: one for the experiment and one for the control. The experimental group received instruction, while the control group received traditional vocabulary instruction. At the end of the course, they took a post-test. The experimental group did better than the control group $(p<0)$.
Bressler, Bodzin, \& Tutwiler (2019) used a collaborative mobile game in science education and its effects on engaging students. In this study, 202 students from two eighth-grade science courses participated in a cooperative, mobile scientific game. A self-report survey was used to gather the information. Three elements were analyzed in this study to determine their relationship with game activity players' flow experience. The elements included achievement track, gender, and group composition. The result displayed that gender affected flow experience. The girls got more flow experience scores. The achievement track had no correlation with flow experience.

\section{Gamified Vocabulary learning}

P. Z. Chen et al. (2020) indicated that because of the characters' fast-talking pace and many new vocabularies, more lexical supports should be prepared in the games. As a result of this research, an adventure game with two versions was created. The first edition was an adventure game, whereas the second included vocabulary drills. Two classes were allocated at random to play two different versions of the game and take pre-, post-, and delayed posttests. A survey was also presented to find out what the participants thought. The study suggested that both groups learned new words, but the experimental group performed better than the control group in both the immediate and delayed post-tests. These results revealed that the adventure game alone could assist contributors in obtaining new words.

Yu (2018) recognized serious gaming as a source of vocabulary growth in English (as a foreign language); researchers employed a mixed-method approach that included two studies and two interviews. In both studies, 
information was gathered from volunteers who were assigned to one of three groups at random: (1) In Group A, learners learned English vocabulary through playing serious games with increased engagement. Hujiang Fun Vocabulary was employed in the first experiment, and New Oriental Fun Vocabulary was used in the second; (2) Students in Group B studied English vocabulary with less interactive serious games, such as Baicizhan in the first experiment and Kingsoft Vocabulary in the second. (3) In both experiments, they learned English vocabulary using typical methods.

At the significance threshold of $p=.05$, it is determined that (1) Interactivity-prone serious gaming is significantly more operative in English vocabulary learning than less interactivity-prone serious gaming; (2) At the significance level of $p=.05$., males significantly outperformed females in serious game-aided English vocabulary learning. (3) At the significance level of $p=.05$., serious gaming is significantly more successful than the traditional strategy in English vocabulary acquisition.

\section{Gamified flipped classroom}

Zou (2020) conducted research on gamified flipped classroom research for elementary learning. The study involved 277 elementary children and eight teachers over the course of a year in a gamified flipped English as a foreign language classroom. In-class observations, interviews, meeting sessions, researcher's observation diaries, and teachers' and students' self-reflection were used to gather data. The information was analyzed using grounded theory and theme analysis. In a gamified flipped classroom, both learners and teachers agreed to raise learning motivation and engagement, promote learning and self-confidence, and improve learning and outcomes. Moreover, there was more time in the classroom for game and interactive activities that helped students apply, analyze, and evaluate the knowledge. This is because professors take into account students' pre-class self-learning and assist them in remembering and understanding the fundamentals.

Sailer \& Sailer (2021) explored the effects of gamification in a flipped classroom. Two hundred five educational science students took part in the study, which included gamified inclass activities such as a gamified quiz with points and a team leader board, as well as nongamified in-class activities such as printed worksheets. The findings revealed that gamification had an indirect effect on application-oriented knowledge, which was aided by learning process performance. Furthermore, gamified in-class activities had positive effects on intrinsic motivation and social relatedness, but had no effect on competence need satisfaction, according to the selfdetermination theory framework.

Gómez-Carrasco, Monteagudo-Fernández, Sainz-Gómez, \& Moreno-Vera (2019) investigated the effects of trainers' use of gamification and a flipped classroom program on students' motivation and perceptions of learning. The 210 participants were allocated into four classroom groups at the University of Murcia (Spain). A perspectives questionnaire was used to gather information. The mean test and Pearson correlations between subscales are provided as descriptive statistics. The study's result indicated the positive effects of motivation and perception of learning. However, there were some differences between group classes and genders. 
Ho (2019) investigated how to teach English story genres using digital sketching and active learning techniques, i.e., story creating and storytelling. It also investigated a gamified flipped classrooms' perceptions of Hong Kong University's students, beyond their understanding of the narrative concepts, taught according to surveys, narrative writing scores, and interviews. This study's finding was to prove that group-based game task students were more effective than discussion tasks. The finding showed that the students who were in gamebased learning reduced their anxiety about using English. Moreover, they had a positive classroom atmosphere and helped the students identify their areas of improvement.

Despite the fact that the flipped classroom and the gamification notion are two distinct applications, they are seen to be compatible. Gamification is a concept that has been around for a long time, with Nick Pelling mentioning the word in 2002 (Marczewski, 2013). Dichev \& Dicheva (2017) conducted a study of 51 empirical studies on gamification in education. Zainuddin (2018) mentioned that gamified flipped classroom is gathered from the mixture of gamification concept and flipped classroom teaching. It is essential to understand that these two terms are different in their definition and operation. Joining the two approaches should have positive results for students learning and educational performance. Reversing the classroom through flipped teaching and using the gamification method provided a chance to engage students, reinforce their learning, and support them with direct feedback on their learning (Nkhoma, Nkhoma, Thomas, \& Tu, 2018). However, there is research on the literature about gamification in education and flipped classroom instruction separately. (Özer, Kanbul, \& Ozdamli (2018) stated that there had been no studies that have analyzed both approaches.

The present study is an attempt to explore the effect of the gamified flipped classroom on the improvement of vocabulary learning in Iranian pre-intermediate EFL learners. Furthermore, this study examines the vocabulary differences between a gamified flipped classroom and traditional learning for Iranian pre-intermediate EFL students. The research aimed to determine whether the gamified flipped classroom has any effect on the improvement of vocabulary learning in Iranian pre-intermediate EFL learners and whether there is any difference between a gamified flipped classroom and traditional vocabulary learning in Iranian pre-intermediate EFL learners in order to achieve the study's objectives.

We expected that a gamified-flipped classroom would have no substantial impact on Iranian EFL students at the pre-intermediate level's vocabulary. The relationships between the experimental and control groups were used to support this hypothesis. On the other hand, we hypothesized that there is no significant association between the gamified flipped classroom and traditional learning when it comes to improving the vocabulary of Iranian pre-intermediate EFL students.

\section{Method}

\section{Participants}

This study involved 110 female EFL learners studying at two high schools in Roodan, a city in Hormozgan province, Iran, in 2019. All the participants were twelfth-grade Iranian 
students. They were chosen non-randomly through handy selection and had the same educational background. Individuals were randomly assigned to one of two groups: experimental or control to begin the study. Three of the lessons were taught by an Iranian non-native English teacher. A placement test of PET was given to the learners on the first day of the study to find out the proficiency levels of participants before the treatment.

\section{Procedure}

The video lectures were prepared by the teacher and were shared in the WhatsApp groups. In every session, some specific vocabulary with some examples and practices were given. The students watched the videos before coming to class and took notes while watching the videos.

During the in-person classes, the teacher applied vocabulary games from Khate-Sefied application to review the vocabulary taught through video lectures. The teacher prepared a game board at school, and each group played the vocabulary games and received scores. In the traditional classroom, the teacher taught vocabulary through conventional training, lecture teaching. A teacher gave some homework to students to do at home for the next session.

\section{Materials}

The material used in this study was Vision3, a book of high school students who studied in grade twelfth. This book is used as a primary instructional sourcebook. According to the standards of the Ministry of Education and Ministry Science, Research, and Technology (MSRT) Iran, the book is mandated. The vocabulary of this book was taught in one semester.

\section{Measurement}

For data collection, different instruments were designed: A placement test of PET was used to find out the proficiency levels of the participants. The Language Center at Oxford University designed this test. Then, a pre-test of vocabulary was given at the first session of the class to understand the students' vocabulary knowledge. A vocabulary test was prepared by the instructor. The reliability and validity of the test were examined by the teacher. The test included 30 multiple questions, and two university professors approved it for validity. The reliability of the test was established by Cronbach's Alpha reliability coefficient $(r=.781)$. A pilot test was designed for a small group of learners, not the target group $(\mathrm{N}=20)$.

On the last day of the project, a multiplechoice post-test was given to test the participants after instruction. This test aims to discover how many words were learned from the gamified-flipped classroom and how many words were learned through nongamified flipped classrooms. Experts agreed on the validity of the test in EFL, and reliability issues of the post-test were addressed.

\section{Data collection}

This study aimed to investigate the influence of the gamified-flipped classroom on improving vocabulary learning by EFL learners. The teacher first offered the students a placement test to determine their level of competency. The teacher administered a pre-test in the first session 
to see whether the target terms that would be taught to the learner were new and unfamiliar to them. As a result, the gamified-flipped classroom and nongamified classrooms received identical information and instructor in one semester. Gamified flipped classrooms would start with watching videos, presenting the vocabulary based on the $12^{\text {th }}$ grade English curriculum before attending the class. The video included the meaning of the words with some examples in appropriate contexts and the correct pronunciation of words. The experimental group was taught with the gamified-flipped classroom approach using teacher-made board games to encourage students' participation by playing board games in a small group as a way to review and assess students' mastery of video content. The teacher monitored the groups and gave feedbacks when necessary.

In the traditional classroom, the contents were taught inside the classroom. The teacher explained each word using visual and example sentences. The teacher asked students to repeat words after the teacher as pronunciation practice. At the end of each session, the teacher gave vocabulary exercises as homework. After teaching vocabulary items, the teacher gave learners a post-test to compare the amount of vocabulary learning in a traditional classroom and those learned through the gamified flipped classroom.

\section{Data analyses}

There were two sets of scores for each group. The data were analyzed in the Statistical Package for the Social Sciences (SPSS) version 25 . The degree of reliability and validity of the test was estimated through the SPSS. The reliability of the pretest and post-test of vocabulary was tested by Cronbach's Alpha.

A paired-sample t-test and an independent t-test in the SPSS (version 25) were used to analyze the data. The comparison was between two sets of scores from the same group of language learners. Before conducting of paired-sample t-test, the Kolmogorov-Smirnov test was used to ensure that the test was normal.

\section{Result and Discussion}

\section{Result}

\section{Descriptive statistics of pre-test and post- test}

The first hypothesis of the present study was that the gamified-flipped classroom has no significant effects on improving the vocabulary of Iranian pre-intermediate EFL learners. In order to obtain the answer, a paired sample t-test was used. Before conducting the t-test, the normality of the distribution was measured. Descriptive statistics and the Kolmogorov-Smirnov test were checked for scores of the gamifiedflipped classroom, the flipped, and the traditional classrooms. The results were presented in the following tables and figures. The descriptive statistics of the scores obtained for the gamified-flipped classroom were presented first. Then, the descriptive statics of the scores obtained from the flipped classroom and traditional classroom were provided. Finally, a paired sample t-test was conducted to answer the first research question. 
Table 1

Descriptive statistic for a pre-test of gamified flipped - vocabulary learning

\begin{tabular}{llllll}
\hline Gamified flipped & $\mathrm{N}$ & Minimum & Maximum & Mean & Std. Deviation \\
\hline Pre- test & 40 & 5.00 & 21.00 & 12.9643 & 3.95795 \\
\hline $\mathrm{N}=28$ & & & &
\end{tabular}

Table 1 displays the descriptive statistics of Kolmogorov-Smirnov checked the normality of pre-test scores of the gamified-flipped the distribution, and the results are shown in classroom in terms of vocabulary learning. Table 2.

Table 2

Kolmogorov-Smirnov result of gamified flipped-vocabulary learning for pre-test

\begin{tabular}{lll}
\hline \multicolumn{2}{l}{ Gamified flipped classroom } & \\
\hline $\mathrm{N}$ & & 40 \\
\hline \multirow{2}{*}{ Normal Parameters ${ }^{\mathrm{a}, \mathrm{b}}$} & Mean & 12.9643 \\
\cline { 2 - 3 } & Std. Deviation & 3.95795 \\
\hline \multirow{2}{*}{ Most Extreme Differences } & Absolute & 0.132 \\
\cline { 2 - 3 } & Positive & 0.132 \\
\cline { 2 - 3 } & Negative & -0.096 \\
\hline Test Statistic & & 0.132 \\
\hline Asymp. Sig. (2-tailed) & $0.200^{\text {c,d }}$ \\
\hline
\end{tabular}

The Sig. value under the Kolmogorov- a value higher than.05, which indicated that the Smirnov part of the table (i.e.,.200) represented distribution of scores was normal.

Table 3

Descriptive statistics for the traditional vocabulary learning

\begin{tabular}{llllll}
\hline \multicolumn{1}{l}{ Descriptive Statistics } & \multicolumn{7}{l}{} \\
\hline & $\mathrm{N}$ & Minimum & Maximum & Mean & Std. Deviation \\
\hline Traditional class & 30 & 7.00 & 18.00 & 14.0000 & 3.01846 \\
\hline $\mathrm{N}=10$ & & & & &
\end{tabular}

As shown in table 3., the mean score of the normality of the distribution of the Kolmogorovtraditional participant was 14.00, and the Smirnov test was applied. standard deviation was 2.48. To ensure the

Table 4

Kolmogorov-Smirnov result of the traditional vocabulary learning for pre-test

\begin{tabular}{lll}
\hline \multicolumn{2}{l}{ Traditional vocabulary learning } & \\
\hline $\mathrm{N}$ & & 30 \\
\hline \multirow{2}{*}{ Normal Parameters ${ }^{\mathrm{a}, \mathrm{b}}$} & Mean & 14.0000 \\
\cline { 2 - 3 } & Std. Deviation & 3.01846 \\
\hline
\end{tabular}




\begin{tabular}{lll}
\hline \multirow{2}{*}{ Most Extreme Differences } & Absolute & 0.200 \\
\cline { 2 - 3 } & Positive & 0.154 \\
\cline { 2 - 3 } & Negative & -0.200 \\
\hline Test Statistic & & 0.200 \\
\hline Asymp. Sig. (2-tailed) & & $0.200 \mathrm{c}, \mathrm{d}$ \\
\hline
\end{tabular}

According to the result of the KolmogorovSmirnov test, the Sig was 0.200 , higher than 0.05 , which proved that the distribution of scores for traditional vocabulary learning was normal.
Table 5. shows the descriptive statistics of the scores of vocabulary learning through the gamified flipped classroom.

Table 5

Descriptive statistics for the gamified-flipped vocabulary learning post-test

\begin{tabular}{llllll}
\hline & N & Minimum & Maximum & Mean & Std. Deviation \\
\hline Gamified-flipped classroom & 40 & 14.00 & 30.00 & 24.0357 & 3.74643 \\
\hline
\end{tabular}

$\mathrm{N}=28$

As shown in the above table, the mean score of the gamified-flipped vocabulary learning was 24.03 , and the standard deviation of the distribution equaled 3.74. Kolmogorov-Smirnov checked the normality of the distribution, and the results are shown in Table 6.

Table 6

Kolmogorov-Smirnov results for the gamified-flipped vocabulary learning post-test

\begin{tabular}{lll}
\hline Gamified flipped classroom learning & & \\
\hline $\mathrm{N}$ & & 40 \\
\hline \multirow{2}{*}{ Normal Parameters $\mathrm{a}, \mathrm{b}$} & Mean & 24.0357 \\
\cline { 2 - 3 } & Std. Deviation & 3.74643 \\
\hline \multirow{3}{*}{ Most Extreme Differences } & Absolute & .137 \\
\cline { 2 - 3 } & Positive & .074 \\
\cline { 2 - 3 } Test Statistic & Negative & -.137 \\
\hline Asymp. Sig. (2-tailed) & & .137 \\
\hline
\end{tabular}

The Sig. value of the Kolmogorov-Smirnov in the table (i.e.,0.188) indicates a value higher than 0.05 , proving that the distribution of scores for the gamified flipped classroom was normal.
Table 7. shows the descriptive statistics of the traditional vocabulary learning scores of the students.

Table 7

Descriptive statistics for the traditional vocabulary learning post-test

\begin{tabular}{llllll}
\hline & $\mathrm{N}$ & Minimum & Maximum & Mean & Std. Deviation \\
\hline Traditional learning & 30 & 14.00 & 23.00 & 18.9000 & 2.96086 \\
\hline
\end{tabular}

$\mathrm{N}=10$ 
As shown in table 7., the mean score of the traditional participants was 18.90 , and the standard deviation was 2.96. In order to ensure

Table 8

Kolmogorov-Smirnov results for the traditional vocabulary learning post-test

\begin{tabular}{|c|c|}
\hline \multicolumn{2}{|l|}{ Traditional vocabulary learning } \\
\hline $\mathrm{N}$ & 30 \\
\hline \multirow{2}{*}{ Normal Parameters $\mathrm{a}, \mathrm{b}$} & 18.9000 \\
\hline & Std. Deviation \\
\hline \multirow{3}{*}{ Most Extreme Differences } & Absolute \\
\hline & Positive \\
\hline & Negative \\
\hline Test Statistic & .161 \\
\hline Asymp. Sig. (2-tailed) & $.200 c, d$ \\
\hline $\begin{array}{l}\text { As the results indicated, the sig value of the } \\
\text { traditional vocabulary, } 0.2 \text {, represented a value } \\
\text { higher than } 0.05 \text {. It means the distribution of } \\
\text { scores for traditional vocabulary learning was } \\
\text { normal. }\end{array}$ & $\begin{array}{l}\text { group and the control (traditional classroom) } \\
\text { group indicate that the distribution of scores } \\
\text { was normal. So, a paired sample t-test was } \\
\text { conducted to compare the learners gamified } \\
\text { flipped classroom vocabulary learning. The } \\
\text { results of this test are presented in table } 9 \text {. }\end{array}$ \\
\hline
\end{tabular}

the normality of the distribution, the Kolmogorov-Smirnov test was applied. the experimental (gamified-flipped classroom)

Table 9

Paired sample t-test results of the Gamified-flipped classroom

\begin{tabular}{|c|c|c|c|c|c|c|c|c|}
\hline & \multicolumn{5}{|c|}{ Paired Differences } & \multirow{3}{*}{$\mathrm{t}$} & \multirow{3}{*}{ df } & \\
\hline & \multirow[t]{2}{*}{ Mean } & \multirow[t]{2}{*}{$\begin{array}{l}\text { Std. } \\
\text { Deviation }\end{array}$} & \multirow{2}{*}{$\begin{array}{l}\text { Std. } \\
\text { Error } \\
\text { Mean }\end{array}$} & \multicolumn{2}{|c|}{$\begin{array}{l}\text { 95\% Confidence } \\
\text { Interval of the } \\
\text { Difference }\end{array}$} & & & $\begin{array}{l}\text { Sig. } \\
\text { (2-tailed) }\end{array}$ \\
\hline & & & & Lower & Upper & & & \\
\hline $\begin{array}{l}\text { Pre- test } \\
\text { Post-test } t\end{array}$ & $\begin{array}{l}- \\
11.07143\end{array}$ & 5.20633 & .98390 & -13.09023 & -9.05263 & -11.253 & 27 & .000 \\
\hline
\end{tabular}

Table 9. indicates that the sig (2-tailed) value for the gamified flipped classroom (experimental-group), (.000), and " $\mathrm{t}$ " value was $(-11.253)$. It means there was a statistically significant difference between the performance of the pre-test and post-test of the experimental group. The findings showed that gamified flipped classrooms significantly outperformed traditional ones.

In order to answer the second research question, an independent t-test was used to compare the experimental and control groups. The results of the tests are indicated in the 
The Effect of Gamified Flipped Classroom on the Improvement of Vocabulary Learning...

Table 10

Results of the independent $t$-test of the gamified-flipped classroom and the traditional classroom

\begin{tabular}{|c|c|c|c|c|c|c|c|c|c|c|}
\hline & & \multicolumn{2}{|c|}{$\begin{array}{l}\text { Levene's } \\
\text { Test for } \\
\text { Equality of } \\
\text { Variances }\end{array}$} & \multicolumn{7}{|c|}{ t-test for Equality of Means } \\
\hline & & \multirow[t]{2}{*}{$F$} & \multirow[t]{2}{*}{ Sig. } & \multirow[t]{2}{*}{$t$} & \multirow[t]{2}{*}{$d f$} & \multirow[t]{2}{*}{$\begin{array}{l}\text { Sig. } \\
(2- \\
\text { tailed })\end{array}$} & \multirow[t]{2}{*}{$\begin{array}{l}\text { Mean } \\
\text { Difference }\end{array}$} & \multirow[t]{2}{*}{$\begin{array}{l}\text { Std. Error } \\
\text { Difference }\end{array}$} & \multicolumn{2}{|c|}{$\begin{array}{l}95 \% \text { Confidence } \\
\text { Interval of the } \\
\text { Difference }\end{array}$} \\
\hline & & & & & & & & & Lower & Upper \\
\hline \multirow[t]{2}{*}{ Vocab } & $\begin{array}{l}\text { Equal } \\
\text { variances } \\
\text { assumed }\end{array}$ & .162 & .690 & 3.909 & 36 & .000 & 5.13571 & 1.31380 & 2.47120 & 7.80023 \\
\hline & $\begin{array}{l}\text { Equal } \\
\text { variances } \\
\text { not } \\
\text { assumed }\end{array}$ & & & 4.375 & 20.050 & .000 & 5.13571 & 1.17386 & 2.68748 & 7.58395 \\
\hline
\end{tabular}

After the normality hypothesis, the homogeneity of group variances was checked by Levene's test. The significance level of this test was more than 0.05 , meaning that the variability in the two conditions was equal. So, the researcher considered the first row of the t-test table as a reference for making statistical interferences. An independent sample t-test was employed to compare the rate of vocabulary learning for the gamified-flipped classroom and the non-gamified flipped classroom learning. The finding showed the $t$ value was 3.909, and Sig equaled 0.000 . According to the findings, there were statistically significant differences in vocabulary learning between the gamified-flipped classroom and non-gamified flipped classroom (traditional learning) $(p<.05)$.

\section{Discussion}

In the present study, flipped learning with gamification promoted students' vocabulary learning. Improvements in the participants' EFL vocabulary learning to some extent learning may lead to vocabulary improvement with playing games in the flipped context. The findings of the study can be summarized as follow. First, in the comparison between the pre-test and post-test of the gamified-flipped classroom, there was a positive effect on the learning of vocabulary for EFL learners. Second, in the comparison between the gamified-flipped classroom and traditional learning( teachercenter classroom), significant positive differences were found between the gamifiedflipped classroom and traditional learning.

In other words, the gamified flipped learning was an effective resource for enhancing the vocabulary knowledge of Iranian female EFL students. This indicates that gamified flipped learning is more helpful in terms of vocabulary learning. A gamified flipped classroom is an effective and useful method that can help students improve vocabulary learning. It can also help the trainers and learners by providing a fun, interesting, and creative condition to get 
better performance in learning a language. The result of the study is in line with (Jo, Jun, \& Lim (2018), who mentioned that the degree of exams after performing gamification was higher than the degree before applying. Moreover, the participants' learning in flip class with using games had statistically significant improvement, in comparison with the traditional flip learning.

In addition, these results are also in agreement with Huang \& Hew (2021), who stated that goal-access-feedback-challengecollaboration classes completed significantly more pre-and post-class activities than nongamified classes. The results support the findings of (Sailer \& Sailer (2021), which indicate that gamification had a positive indirect effect on application-oriented knowledge in a flipped classroom context. The result of the present study is also in line with Huang, Hew, \& Lo (2019), demonstrating that students in the flipped learning with gamification class outperformed those in a traditional and online independent study. The findings of the present study were consistent with other previous studies.

\section{Limitations and future directions}

This study has some limitations that should be addressed in future research. This study is restricted in teaching vocabulary, in which other skills of language such as grammar, writing, and reading are ignored. All data in this study were collected from pre-intermediate English learners studying at two high schools in Roodan, Hormozgan, Iran. So, the results obtained by studying participants may not be generalizable to others with different proficiency levels or vocabulary sizes. The number of pedagogical games that are related to target vocabularies is limited. Moreover, in developing board games for classrooms, teachers are strongly encouraged to go beyond the question and answer structure by integrating diverse game mechanics to keep their students motivated.

Therefore, the results need to be inferred with caution, given that these findings might not be transferable to the study of the students of other countries. The impact of gamified flipped learning on L2 was explored in this research study. For practical reasons, the study was restricted to L2 English. So, there may be good value in future studies looking at other L2s if gamified flipped learning affects teaching and learning them or not.

\section{Conclusion}

The present study aimed to investigate the effect of the gamified-flipped classroom on improving vocabulary learning of Iranian preintermediate EFL learners. According to the results of the data analysis, the gamified flipped classroom, in general, had a positive influence on learning vocabulary. The instruction of vocabulary was integrated into the flipped classroom with gamification. The vocabulary scores of the pre-test and the post-test were analyzed. According to the test findings, the flipped classroom with gamification has a positive effect on vocabulary learning.

According to the findings of the study, the use of gamified flipped classrooms has a significant effect on the learners' vocabulary improvement. By looking at the difference between the mean score of pre-test and post-test of the gamified and non-gamified flipped classroom, the gamified flipped classroom was more effective than the traditional classroom. 


\section{Acknowledgment}

We thank all the people who have supported us to complete the research work directly or indirectly.

\section{References}

Alavi, G., \& Gilakjani, A. P. (2019). The Effectiveness of Games in Enhancing Vocabulary Learning among Iranian Third Grade High School Students. Malaysian Journal of Elt Research, 16(1).

Bavi, F. (2018). The Effect of Using Fun Activities on Learning Vocabulary at the Elementary Level. Journal of Language Teaching and Research, 9, 629. https://doi.org/10.17507/jltr.0903.24

Bressler, D., Bodzin, A., \& Tutwiler, M. (2019). Engaging middle school students in scientific practice with a collaborative mobile game. Journal of Computer Assisted Learning, 35. https://doi.org/10.1111/jcal.12321

Burguillo, J. (2010). Using game theory and Competition-based Learning to stimulate student motivation and performance. Computers \& Education, 55, 566-575. https://doi.org/10.1016/j.compedu.2010 .02 .018

Chen, C. M., \& Chung, C. J. (2008). Personalized mobile English vocabulary learning system based on item response theory and learning memory cycle. Computers and Education, 51(2). https://doi.org/10.1016/j.compedu.2007 .06 .011

Chen, H. R., \& Lin, Y. S. (2016). An examination of digital game-based situated learning applied to Chinese language poetry education. Technology, Pedagogy and Education, 25(2). https://doi.org/10.1080/1475939X.2015. 1007077

Chen, P. Z., Chang, T. C., \& Wu, C. L. (2020). Effects of gamified classroom management on the divergent thinking and creative tendency of elementary students. Thinking Skills and Creativity, 36.

https://doi.org/10.1016/j.tsc.2020.1006 64

Dichev, C., \& Dicheva, D. (2017). Gamifying education: what is known, what is believed and what remains uncertain: a critical review. International Journal of Educational Technology in Higher Education, Vol. 14. https://doi.org/10.1186/s41239-0170042-5

Girmen, P., \& Kaya, M. F. (2019). Using the Flipped Classroom Model in the development of basic language skills and enriching activities: Digital stories and games. International Journal of Instruction, 12(1). https://doi.org/10.29333/iji.2019.12136 a

Gómez-Carrasco, C. J., MonteagudoFernández, J., Sainz-Gómez, M., \& Moreno-Vera, J. R. (2019). Effects of a Gamification and Flipped-Classroom Program for Teachers in Training on Motivation and Learning Perception. Education Sciences 2019, Vol. 9, Page 299, 9(4), 299. https://doi.org/10.3390/EDUCSC1904029 9

Goodwin, B. (2013). Evidence on flipped classrooms is still coming in. Educational Leadership, 70(6).

Goulden, R., Nation, P., \& Read, J. (1990). How large can a receptive vocabulary be? Applied Linguistics, 11(4). https://doi.org/10.1093/applin/11.4.341

Ho, J. (2019). Gamifying the flipped classroom: how to motivate Chinese ESL learners? Innovation in Language Learning and Teaching, 14, 1-15. https://doi.org/10.1080/17501229.2019. 1614185

Huang, B., \& Hew, K. (2021). Using 
Gamification to Design Courses: Lessons Learned in a Three-year Design-based Study. Educational Technology \& Society, 24, 44-63.

Huang, B., Hew, K. F., \& Lo, C. K. (2019). Investigating the effects of gamificationenhanced flipped learning on undergraduate students' behavioral and cognitive engagement. Interactive Learning Environments, 27(8), 11061126.

https://doi.org/10.1080/10494820.2018. 1495653

Huizenga, J., Admiraal, W., Akkerman, S., \& Dam, G. (2009). Mobile game-based learning in secondary education: Engagement, motivation and learning in a mobile city game. J. Comp. Assisted Learning, 25, 332-344. https://doi.org/10.1111/j.13652729.2009.00316.x

Jo, J., Jun, H., \& Lim, H. (2018). A comparative study on gamification of the flipped classroom in engineering education to enhance the effects of learning. Computer Applications in Engineering Education, 26. https://doi.org/10.1002/cae.21992

Jong, B.-S., Lai, C.-H., Hsia, Y.-T., Lin, T.-W., \& Lu, C.-Y. (2013). Using Game-Based Cooperative Learning to Improve Learning Motivation: A Study of Online Game Use in an Operating Systems Course. IEEE Trans. on Educ., 56(2), 183190. https://doi.org/10.1109/TE.2012.220795 9

Laufer, B. (2001). Quantitative evaluation of vocabulary: how it can be done and what it is good for.

Marczewski, A. (2013). Gamification: A Simple Introduction. Retrieved from https://books.google.co.id/books?id=IOu 9kPjIndYC

Nkhoma, C., Nkhoma, M., Thomas, S., \& Tu, L. (2018). Gamifying a flipped first year accounting classroom using Kahoot! International Journal of Information System and Engineering, 6, 93-115. https://doi.org/10.24924/ijise/2018.11/v 6.iss2/93.115

Özer, H., Kanbul, S., \& Ozdamli, F. (2018). Effects of the Gamification Supported Flipped Classroom Model on the Attitudes and Opinions Regarding GameCoding Education. International Journal of Emerging Technologies in Learning (IJET), 13, 109. https://doi.org/10.3991/ijet.v13i01.7634

Reinders, H., \& Wattana, S. (2015). Affect and willingness to communicate in digital game-based learning. ReCALL, 27(1). https://doi.org/10.1017/S095834401400 0226

Sailer, M., \& Sailer, M. (2021). Gamification of in-class activities in flipped classroom lectures. British Journal of Educational Technology, 52(1), 75-90. https://doi.org/10.1111/bjet.12948

Sams, A., \& Bergmann, J. (2013). Flip your students' learning. Educational Leadership, 70(6).

Toto, R., \& Hien Nguyen. (2009). Flipping the Work Design in an industrial engineering course. 2009 39th IEEE Frontiers in Education Conference, 1-4. https://doi.org/10.1109/FIE.2009.53505 29

Turgut, Y., \& Irgin, P. (2009). Young learners' language learning via computer games. Procedia - Social and Behavioral Sciences, 1(1). https://doi.org/10.1016/j.sbspro.2009.0 1.135

Wilkins, D. A. (1972). Linguistics in Language Teaching. London: The MIT Press.

Wu, W. H., Hsiao, H. C., Wu, P. L., Lin, C. H., \& Huang, S. H. (2012). Investigating the learning-theory foundations of gamebased learning: A meta-analysis. Journal of Computer Assisted Learning, 28(3). https://doi.org/10.1111/j.1365- 
The Effect of Gamified Flipped Classroom on the Improvement of Vocabulary Learning...

2729.2011.00437.x

Yu, Z. (2018). Differences in serious gameaided and traditional English vocabulary acquisition. Computers \& Education, 127, 214-232.

https://doi.org/10.1016/j.compedu.2018 .07 .014

Zainuddin, Z. (2018). Students' learning performance and perceived motivation in gamified flipped-class instruction.
Computers \& Education, 126.

https://doi.org/10.1016/j.compedu.2018 .07 .003

Zou, D. (2020). Gamified flipped EFL classroom for primary education: student and teacher perceptions. Journal of Computers in Education, 7(2). https://doi.org/10.1007/s40692-02000153-w 
Farhad Fahandezh, Asieyeh Mohammadi 